УДК 03:340.12

\title{
Юрій Шемшученко
}

академік НАН України,

Інститут держави і права ім. В. М. Корецького НАН України, директор

\section{Фундаментальний звід знань про державу і право}

Указом Президента України від 9 грудня 2004 р. колективу авторів 6-томної «Юридичної енциклопедії», виданої у 1998-2004 роках, було присуджено Державну премію України в галузі науки і техніки. Високої державної нагороди удостоєні науковці Інституту держави і права ім. В. М. Корецького НАН України, під егідою якого готувалася і видавалася Енциклопедія, а саме: В. П. Горбатенко, В. Н. Денисов, О. М. Мироненко, В. П. Нагребельний, В. Ф. Погорілко, В. І. Семчик, І. Б. Усенко й автор цих рядків. Лауреатами премії також стали ректор Національної юридичної академії України ім. Ярослава Мудрого В. Я. Тацій та М. П. Зяблюк - директор видавництва «Українська енциклопедія» ім. М. П. Бажана.

«Юридична енциклопедія» є першою не тільки в Україні, а й на всьому пострадянському просторі Енциклопедією такого типу. Це фундаментальний звід знань про державу і право, заснований на досягненнях як світової, так і національної юридичної думки. Вона видана тиражем 30 тисяч примірників і має велике значення для розбудови демократичної і правової держави та громадянського суспільства в Україні. Енциклопедію можна вважати також кроком уперед у розвитку вітчизняної теоретичної юридичної думки.

Наш досвід підготовки і видання «Юридичної енциклопедії» має чимало особливостей. Це може становити інтерес для тих, хто зараз задіяний у підготовці інших енциклопедій соціогуманітарного характеру, а також для більш широкого загалу.

Ідея підготовки «Юридичної енциклопедії» у нас зародилася невдовзі після проголошення незалежності України. Вже 1 березня 1993 р. Інститут надіслав листа першому Президентові України Л. М. Кравчуку такого змісту:

\section{«Вельмишановний Леоніде Макаровичу!}

Побудова незалежної правової Украӥнської держави передбачає необхідність істотного розширення знань про державу і право серед населення та різних груп фахівців і політичних діячів - депутатів, адміністраторів, підприємців, праців- 
ників правоохоронних органів тощуо. Нові прочеси державотворення вимагають системного роз'яснення багатьох нових понять і термінів у галузі юриспруденціі. Зважаючи на цее, є гостра потреба у виданні в Україні «Юридичної енциклопедї̈» y 10-ти томах по 60-70 друкованих аркушів кожний. Підготовку до видання цієї вкрай необхіднї роботи міг би взяти на себе Інститут держави і права ім. В. М. Корецького АН Украӥни, який вже має відповідний досвід роботи у иій сфері. До підготовки енџиклопедії, крім того, передбачається залучити провідних юристів з усіх юридичних наукових установ і вузів України, а також досвідчених юристів-практиків. Строк підготовки і видання Енциклопедії-до 2000 р.

Енщиклопедія буде охоплювати всі основні юридичні терміни і поняття з усіх галузей права, ї̈ видання випливає із затвердженого Верховною Радою України 16 жовтня 1992 р. пріоритетного напряму наукових досліджень - наукові проблеми розбудови державності України.

На жаль, видання «Юридичної енциклопедї̈» - изе на сьогодні не тільки складна, а й коштовна справа. Інститут не має відповідних коштів для изього. У зв'язку з ичим і враховуючи, щуо иче питання має державне значення, просимо розглянути його і прийняти рішення щуодо видання Енциклопедії $і$ забезпечення цุього процесу необхідними коштами».

Леонід Макарович надіслав цього листа на розгляд тодішньому віце-прем'єрміністрові України, академікові АН України М. Г. Жулинському, який передав лист на узгодження до відповідних міністерств і відомств, що, на жаль, не дало позитивного результату.

Тоді ми вирішили діяти через Президію АН України. На її засіданні 8 вересня 1993 р. було обговорено мою доповідь з відповідного питання. Ідею видання багатотомної «Юридичної енциклопедії» підтримав президент АН України Б. С. Патон. Президія АН України прийняла постанову «Про підготовку фундаментальної «Юридичної енциклопедії», якою, зокрема, було передбачено: «Вважати підготовку і видання «Юридичної енциклопедії» у 6 томах одним із пріоритетних напрямів у розгортанні фундаментальних досліджень у галузі соціальних і гуманітарних наук». Було схвалено склад редакційної колегії, а Інститут держави і права АН України зобов'язали підготувати проект концепції Енциклопедії. Президія також визнала за доцільне звернутися до Кабінету Міністрів України 3 клопотанням щодо виділення коштів для фінансування цього проекту.

Далі в Інституті розпочалися підготовчі роботи, зокрема, було розроблено концепцію Енциклопедії і складено тезаурус ії основних термінів. Але через відсутність коштів роботу довелося тимчасово припинити. До неї ми повернулися після прийняття 29 лютого 1996 р. Кабінетом Міністрів України постанови «Про державну підтримку видання «Юридичної енциклопедії», яку підписав тодішній Прем’єр-міністр України С. К. Марчук. За цією постановою проект отримав форму державного замовлення з відповідним фінансуванням. Організаційне та нау- 
ково-методичне забезпечення підготовки 6-томної «Юридичної енциклопедії» було покладено на Інститут держави і права ім. В. М. Корецького НАН України та редакційну колегію. Саме ж видання Енциклопедії мало забезпечити Міністерство у справах преси та інформації України. Останнє доручило цю справу безпосередньо видавництву «Українська енциклопедія» ім. М. П. Бажана та типографії «Поліграфкнига».

До основного складу авторського колективу Енциклопедії увійшли науковці Інституту. До підготовки тексту були залучені також провідні правознавці з інших юридичних науково-дослідних установ, вищих навчальних закладів та висококваліфіковані юристи-практики. Організаційним осередком роботи став спеціально створений для цього у складі Інституту Центр з підготовки «Юридичної енциклопедії».

Наполеглива праця колективу і належним чином організована робота дали свої плоди. Вже у 1998 р. побачив світ перший том Енциклопедії. Потім майже щороку з'являлися наступні томи. У 2004 р. проект було завершено.

Що ж становить собою «Юридична енциклопедія»? Насамперед, це - паспорт правової держави, багатогалузеве і багатоаспектне видання, що є системою знань про державу і право.

Переважна більшість уміщених в Енциклопедії статей про поняття і категорії (передусім, загальної теорії держави та права, філософії і соціології права) враховують найновіші вітчизняні й світові досягнення в галузі юриспруденції. Автори намагалися уникнути існуючих досі у соціогуманітарних науках ідеологічних нашарувань, штампів, стереотипів. Такий підхід $є$ виправданим, оскільки трансформація пострадянських країн навряд чи можлива без переосмислення соціальноекономічних набутків минулого, а, особливо - без переосмислення в галузі державознавства, права, філософії права. Адже відомо, що розвиток будь-якого суспільства відбувається саме через модернізацію державно-правових відносин, перетворення правових приписів на правосвідомість мільйонів.

Так, розкриваючи у другому томі видання поняття «держава», автори дійшли висновку, що держава - це сукупність людей, території, на якій вони проживають, і суверенної у межах цієї території влади. У цьому розумінні термін «держава» тотожний поняттям «країна» та «основний суб’єкт міжнародного права». Однак 3 юридичної точки зору держава тлумачиться як організація політичної влади, головний інститут політичної системи суспільства, який спрямовує та організовує за допомогою норм права спільну діяльність людей і соціальних груп, захищає права та інтереси громадян. Акумулюючи у своїх руках владні повноваження, держава політично інтегрує суспільство і представляє його як у внутрішніх, так i в зовнішніх відносинах. За всієї різноманітності держав за формами правління, державного устрою, політичним режимом загальною тенденцією нині є зростання ролі держави у вирішенні проблем суспільного розвитку. Найприйнятнішою 
моделлю при цьому справедливо визнається держава, яка основою своєї діяльності вважає задоволення прав та інтересів людини і громадянина. Ці концептуальні положення покладені в основу всіх статей, присвячених теорії і практиці діяльності держави та їі органів, функціям державних інституцій, історичним тенденціям і перспективам розвитку держави.

Великий масив Енциклопедії становить теоретико-правова проблематика: статті про поняття і зміст права, правовідносини, правосвідомість, правову культуру, про галузі права, основні вітчизняні та зарубіжні державно-правові школи і вчення тощо. Вона містить чимало понять з інших галузей юриспруденції, які нині переосмислено по-новому, і які відображають процес суверенізації України, кардинальних змін у суспільних відносинах, реформування національної правової системи, мають безпосередній зв'язок із життям людини та юридичною практикою.

Слід зазначити, що багатотомна «Юридична енциклопедія» концептуально побудована як універсальний звід знань про державу і право. Враховуючи цю обставину, iї авторський колектив широко представив історико-правову проблематику, яка, зокрема, охоплює суспільно-політичний і державний устрій України на всіх етапах їі розвитку, державні та юридичні інституції минулого, пам’ятки українського права, еволюцію політико-правової думки видатних вітчизняних учених-юристів минулого тощо. Характерним є те, що історію держави і права України висвітлено як складову загальної історії держави та права, що значною мірою відображає національні та регіональні особливості України, оскільки, як відомо, історія української державності та права свого часу розглядалася лише в межах історії держави та права сусідніх країн (насамперед Росії, Литви та Польщі). Значну частину історикоюридичного матеріалу введено у вітчизняний науково-правовий обіг уперше.

Змістовним у «Юридичній енциклопедії» є розкриття основних положень Конституції України 1996 року як основного політико-правового акта держави. У всіх томах в алфавітному порядку подано цикли статей, присвячених сутності конституційного права, свобод та обов'язків людини і громадянина, референдуму, виборчого права, адміністративно-територіального устрою країни, структури влади, конституційного будівництва тощо. Ці статті можна вважати вагомим внеском у розвиток конституційного права, виборчої системи, парламентаризму, теорії і практики державотворення, місцевого самоврядування.

Значну наукову цінність мають матеріали «Юридичної енциклопедії» і щодо змісту, структури та функцій державного управління, основних понять і категорій адміністративного права та адміністративного процесу, правового статусу практично усіх органів державної виконавчої влади, а також органів місцевого самоврядування і об’єднань громадян в Україні.

Велику увагу в Енциклопедії приділено органам судової влади, структурній побудові та правовим засадам організації і діяльності судової системи України, органам юстиції, прокуратури, адвокатури та нотаріату, змісту і принципам законнос- 
ті й дотримання правопорядку у діяльності державних органів. Грунтовність матеріалу з цієї проблематики має непересічне наукове і практичне значення, оскільки слугуватиме науковому забезпеченню судової реформи, зміцненню законності, подоланню правового нігілізму, підвищенню рівня правової компетенції суддів, державних службовців та громадян. Велике пізнавальне та інформаційно-довідкове значення мають і відомості про юридичні науково-дослідні установи та навчальні заклади, про міжнародні та національні (державні та громадські) правові інституції, а також про основні зарубіжні та вітчизняні юридичні періодичні видання.

У багатотомній науковій праці з урахуванням нового законодавства України та новітніх досягнень юридичної науки детально й усебічно проаналізовано зміст основних понять фінансового, бюджетного, податкового, митного, банківського, валютного, інвестиційного та господарського законодавства, а також висвітлюються актуальні проблеми, пов'язані з організацією і державно-правовим регулюванням ринкових відносин, юридичним змістом основних економічних категорій і понять.

Значне місце в Енциклопедії відведено статтям, присвяченим теорії та практиці застосування приватного права, зокрема таких галузей, як цивільне, підприємницьке, сімейне, трудове право. Характерно, що в Енциклопедії широко відображено правовий режим усіх форм власності - приватної, державної, муніципальної, власності українського народу, а також правовий статус юридичних осіб усіх організаційно-правових форм приватного і публічного права та господарської діяльності в цілому.

Вагоме наукове і практичне значення, на наш погляд, матимуть вміщені в «Юридичній енциклопедії» грунтовні статті 3 питань сучасного земельного, аграрного та екологічного права, а також нових галузей законодавства і права: енергетичного, ядерного, космічного. Велику увагу приділено й основним інститутам цивільно-процесуального права, міжнародного арбітражного та вітчизняного господарського судочинства. Численні статті з цієї тематики містять аналіз і систематизовану характеристику відповідного законодавства, а також узагальнення судово-арбітражної практики, що у подальшому може з успіхом використовуватися для вдосконалення правового регулювання процесуальних відносин, у практичній діяльності господарських і третейських судів, з навчальною метою тощо.

Актуальні проблеми судово-правової реформи в Україні, зміцнення законності та правопорядку, боротьба з правопорушеннями, забезпечення конституційних прав та свобод громадян дедалі частіше розглядаються в контексті розвитку теорії і практики кримінального права в умовах демократизації суспільних відносин, а також реформування кримінально-процесуального і пенітенціарного законодавства. Практично в усіх шести томах видання на високому методологічному рівні висвітлено ці проблеми та узагальнено відповідні публікації з кримінальноправових дисциплін, кримінології та криміналістики. 
Авторським колективом «Юридичної енциклопедії» послідовно і грунтовно викладено всебічну, науково-виважену інформацію не тільки про вітчизняні набутки в царині юридичних наук (відкриваючи при цьому малознайомі або й призабуті імена), але й висвітлено категорії, поняття, доктрини та наукові школи права, що домінують у демократичних суспільствах. Крім того, у другому - п'ятому томах Енциклопедії проаналізовано понад 300 конвенцій - важливих міжнародно-правових документів, які стали (або стають) нормами життя багатьох країн, вміщено відомості про основні міжнародні організації, об’єднання, спеціалізовані установи, міжурядові організації та інші міжнародні формування.

Відомо, що для України проблема примату міжнародного права, а також проблема дії його норм як органічної складової національної правової системи є надзвичайно важливими. За роки незалежності Україна як суверенна держава ще не змогла виробити стабільних демократичних форм і державної практики стосовно функціонування в їі внутрішньому праві усталених норм міжнародного права. Разом $з$ тим їі європейський вибір, який часто й надміру політизується і спотворюється переважно представниками ортодоксальних партій та рухів, означає не що інше, як орієнтацію на європейські цінності - на повагу прав і свобод людини, іiі гідності, честі, недоторканності, на гуманістичний вибір подальшого розвитку суспільства. За своєю спрямованістю гармонізація та адаптація національних нормативно-правових актів до вимог законодавства Європейського Союзу та міжнародно-правових стандартів - це, по суті, адаптація до системи юридичних цінностей, що визначає відповідні стандарти суспільного життя. Тому характерним для «Юридичної енциклопедії» є наявність у ній великого масиву грунтовних і новаторських статей з історії і теорії міжнародного права, практики міжнародних публічних відносин, участі України у формуванні сучасного міжнародного правопорядку.

Інтерес становлять також статті про статус ООН та іiі інституції, міжнародні договори, угоди, конвенції, декларації та інші документи, створені за участю України або які безпосередньо стосуються України, а також матеріали, що містять узагальнену довідково-аналітичну інформацію про державний устрій та правову систему практично усіх країн світу.

Наукова та навчально-освітня значущість Енциклопедії полягає і в тому, що тільки з цього видання (принаймні сьогодні) можна дізнатися у стислій і доступній формі про вітчизняні та основні зарубіжні державно-правові школи і вчення, про українських правознавців і юристів-практиків, визначних національних та зарубіжних державних і громадських діячів. 3 найвідоміших постатей минулого до видання увійшли статті про діячів та вчених, які істотно вплинули на державотворчі і правотворчі процеси в своїх країнах, залишили помітний слід у вітчизняному та міжнародному праві, юридичній науці в цілому. 
Загалом «Юридична енциклопедія» містить близько 10 тисяч термінів. У iï підготовці взяли участь понад 500 авторів. Це не тільки правознавці, серед авторів є також історики, філософи, політологи тощо. Низку статей підготували зарубіжні фахівці.

За своїм характером «Юридична енциклопедія» є універсальною, хоча нею не вичерпується усе різноманіття юридичної тематики. Під цим кутом зору Інститут держави і права ім. В. М. Корецького НАН України продовжує енциклопедичні дослідження. Заплановано підготувати низку галузевих енциклопедичних видань, зокрема: «Енциклопедія міжнародного права», «Енциклопедія європейського права», «Енциклопедія права інтелектуальної власності» та інші. Триває також робота над «Великим юридичним енциклопедичним словником», який міститиме терміни чинного («живого») права. Усі ці видання сприятимуть підвищенню правосвідомості і правової культури населення, що є ключовою засадою для побудови правової держави. 